\title{
Short Helical Blade for Treatment of Inter- trochanteric Hip Fractures in Elderly Patients
}

\author{
*Ricardo Monreal, Enrique Faedo and Paul Ide la Cruz \\ Centro Médico MEDEX, República de Panamá 3065 2do piso, Perú
}

Submission: February 22, 2017; Published: March 09, 2017

*Corresponding author: Ricardo Monreal, MD, Clinicas Maison de Sante, Ave. Chorrillos 171, Chorrillos, Lima, Peru; Email: rmonreal59@yahoo.es

\section{Introduction}

Hip fractures in the geriatric population cause short and long term pain, impaired function, and reduced quality of life. The overall one year mortality after hip fractures for the elderly patients is high (approximately 20-25\%) [1]. One-half of all hip fractures are intertrochanteric fractures [2].

The conventional osteosynthesis for intertrochanteric fractures include sliding hip screws (DHS) and intramedullary nail (gamma nail, PFN) continues to be unacceptable even if increasing age and co-morbidity of patients are taken into account. Although the use, intramedullary devices have become increasingly popular, particularly amongst teaching institutions and younger surgeons [2,3], the optimal choice of stabilization remains controversial.Therefore, new intramedullary techniques are under development, and we report our results with the Trochanteric Femoral Nail (TFN) in treatment of trochanteric fractures.

\section{Patients and Methods}

Eleven patients(over the age of 65 years) between the years 2012 and 2015 with intertrochanteric fracture (Figure 1) were treated withshort cephalomedullary device (Synthesis TFN).

The operations were all performed under spinal anesthesia with the use of an image intensifier. Patient is positioned on fracture table with traction supine, and under image intensifier fracture reduction is done (Figure 2). After TFN is inserted, a post-operative $\mathrm{x}$-ray (Figure 3) was taken to check the reduction and alignment. The patient was mobilized on third day with the help of the walker and partial weight bearing, and discharged on the fifth day to review on 12th post-operative day for suture removal. After first month and third month (Figure 4) check $\mathrm{X}$-ray was done to see the fracture heal and prognosis. All patients were grade with Harris Hip Score [4] for the outcome on 12 th month.
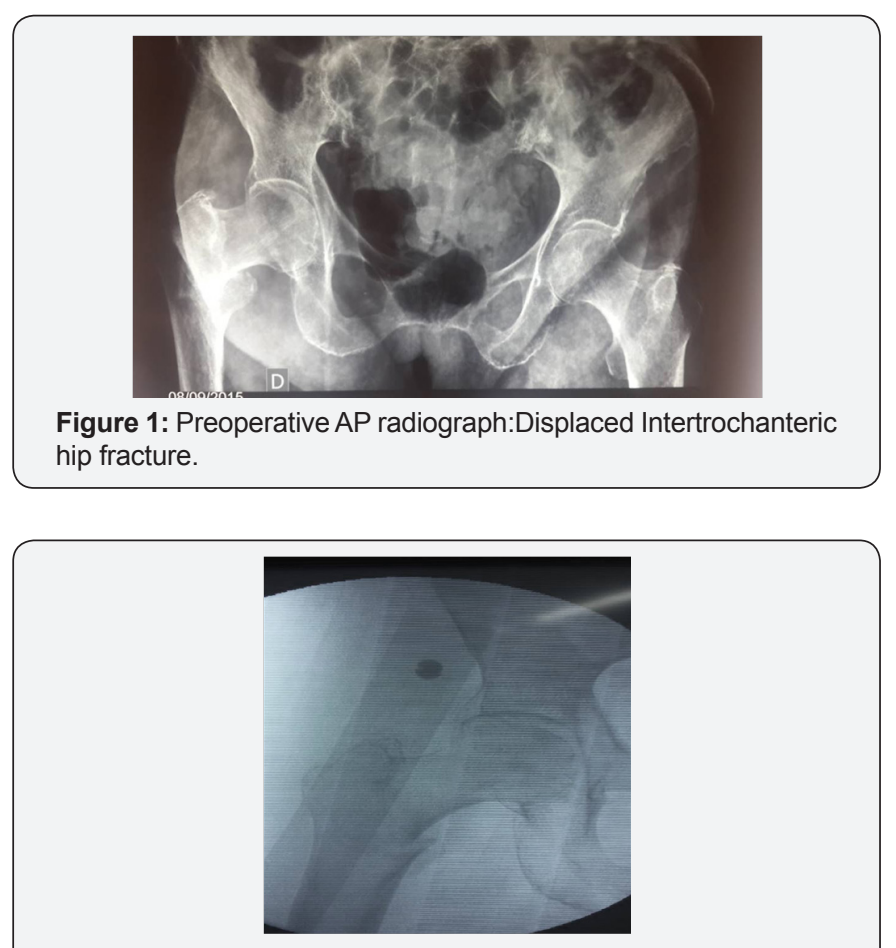

Figure 2: Fracture reduction under image intensifier.

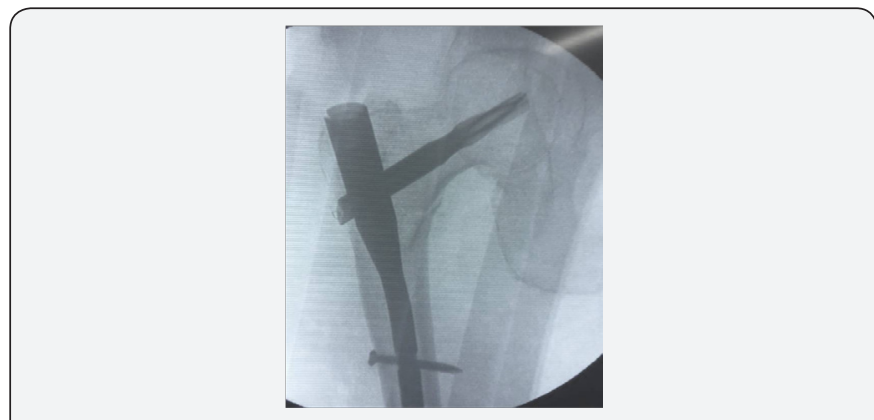

Figure 3: Post-operative x-ray. Open reduction and internal fixation with a short (TFN) intramedullary nail. 


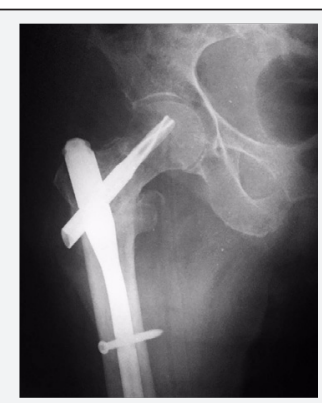

Figure 4: Third month post-operative $\mathrm{X}$-ray: fracture heals is observed.

A retrospective chart review of all available documentation for these patients was conducted beginning allowing for a minimum one-year follow-up from surgery for all patients.

\section{Results}

The study population consisted of 11 patients: 2 males and 9 females with an average age of 76.8 years. There were no mortalities during the first 90 days after surgery. All patients had sufficient follow-up for final analysis. The average operative time was $1 \mathrm{hr} 10 \mathrm{~min}$ (1to $2 \mathrm{hr}$ ) and the average length of hospital stay was 7.15 days.

Five patients required blood transfusions post-operatively. There were no infections, non-unions, malunions, periprostheticfractures, or complications from the intramedullary deviceduring the study period.At 3rd month follow up x-rays were taken and reduction was good in all the case and pain was normal.Hip score at the end of 12 months was excellent $45.5 \%$, good in $27.3 \%$, fair in $18.1 \%$ and poor in $9.1 \%$ (Table 1).

Table1: Results of short intramedullary nailing of intertrochanteric hip fractures.

\begin{tabular}{|c|c|c|c|c|}
\hline Variable & \multicolumn{4}{|c|}{ Outcome } \\
\hline Total Number of Patients & \multicolumn{4}{|c|}{11} \\
\hline $\begin{array}{c}\text { Average Length of Hospital } \\
\text { Stay }\end{array}$ & \multicolumn{4}{|c|}{$1 \mathrm{hr} 10 \mathrm{~min}(1$ to $2 \mathrm{hr}$ ) } \\
\hline 90-day mortality & \multicolumn{4}{|c|}{$5 / 11(45.5 \%)$} \\
\hline $\begin{array}{c}\text { Average Length of Hospital } \\
\text { Stay }\end{array}$ & \multicolumn{4}{|c|}{7.15 days } \\
\hline 90-day mortality & \multicolumn{4}{|c|}{$0 / 11$} \\
\hline Infections & \multicolumn{4}{|c|}{$0 / 11$} \\
\hline Nonunions & \multicolumn{4}{|c|}{$0 / 11$} \\
\hline Malunions & \multicolumn{4}{|c|}{$0 / 11$} \\
\hline Implant complications & $0 / 11$ & Good & Fair & Poor \\
\hline Harris Hip Score & $\begin{array}{c}5 \\
(45.5 \%)\end{array}$ & $\begin{array}{c}3(27.3 \\
\%)\end{array}$ & $\begin{array}{c}2(18.1 \\
\%)\end{array}$ & $\begin{array}{c}1 \\
(9.1 \%)\end{array}$ \\
\hline
\end{tabular}

\section{Discussion}

A wide range of proximal femoral fracture fixation devices have been employed over the years and the sliding compression hip screw and side plate, became the implant of choice for the fixation of intertrochanteric fractures in the latter half of the twentieth century [5-7].

Antegrade intramedullary nailing of intertrochanteric fractures with use of a short nail through which a large screw was inserted into the femoral neck and head for interlocking was introduced by Halder in the 1980s in the form of the Gamma nail [8]. Early reports using this device designed by Grosse and Kempf in Strasbourg, France suggested some substantial advantages. However, there was a high rate of technical complications, including fracture of the femur distal to the nail $[9,10]$. The device was redesigned in 1997 to become the Trochanteric Gamma nail, with a smaller lateral bend, a shorter overall length, and only one distal interlocking screw.

The use of short intramedullary devices in the management of elderly patients with intertrochanteric fractures of the hip is controversial. While some studies have identified increased rates of femoral fracture with IMN, it is important to take into account the surgeon experience and the improvements in implant design. Other studies have found that there is in fact a steep learning curve associated with the IMN, with more experienced surgeons having improved results and decreased complication rates [11-13]. In the present study, we found that the use of a short intramedullary device (Synthes TFN) for the treatment of intertrochanteric hip fractures in elderly patient achieved good outcomes at one year with no device-related complications.

The results of our study have shown that the use of a short intramedullary device (Synthes TFN) to treat intertrochanteric hip fractures in elderly patient achieved good outcomes at one year with no device-related complications.

The present study is limited due its retrospective design, small series and no control group.

\section{Conclusion}

In this small patient group TFN shown good outcome with no complications after treatment.

\section{Statement of Informed Consent}

All study participants provided informed written consent prior to study enrollment.

\section{Statement of Human Rights}

All procedures followed were in accordance with the Helsinki Declaration of 1975, as revised in 2008. Informed consent was obtained from all patients for being included in the study. 


\section{References}

1. Leibson CL, Tosteson A, Gabriel Se, Ransom JE, Melton LJ (2002) Mortality, disability, and nursing home use for persons with hip fracture: a population based study. J Am Geriatr Soc 50(10): 16441650 .

2. Anglen JO, Weinstein JN (2008) American Board of Orthopaedic Surgery Research Committee. Nail or plate fixation of intertrochanteric hip fractures: changing pattern of practice. A review of the American Board of Orthopaedic Surgery Database. J Bone Joint Surg Am 90(4): 700-707.

3. Forte ML, Virnig BA, Kane RL, Durham S, Bhandari M, et al. (2008) Geographic variation in device use for intertrochanteric hip fractures. J Bone Joint Surg Am 90(4): 691-699.

4. Harris WH (1969) Traumatic arthritis of the hip after dislocation and acetabular fractures: treatment by mold arthroplasty. An end-result study using a new method of result evaluation. J Bone Joint Surg Am 51(4): 737-755.

5. Leung KS, So WS, Shen WY, Hui PW (1992) Gamma nails and dynamic hip screws for peritrochanteric fractures. A randomised prospective study in elderly patients. J Bone Joint Surg Br 74(3): 345-351.

6. Kyle RF, Gustilo RB, Premer RF (1979) Analysis of six hundred and twenty-two intertrochanteric hip fractures. J Bone Joint Surg Am 61(2): 216-221.

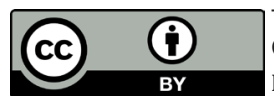

This work is licensed under Creative Commons Attribution 4.0 License

DOI:_10.19080/OROAJ.2017.05.555656
7. Clawson DK (1964) Trochanteric fractures treated by the sliding screw plate fixation method. J Trauma 4: 737-752.

8. Halder SC (1992) The Gamma nail for peritrochanteric fractures. J Bone Joint Surg Br 74(3): 340-344.

9. Boriani S, De Iure F, Bettelli G, Specchia L, Bungaro P, et al. (1994) The results of a multicenter Italian study on the use of the Gamma nail for the treatment of pertrochanteric and subtrochanteric fractures: a review of 1181 cases. Chir Organi Mov 79(2): 193-203.

10. Hardy DC, Descamps PY, Krallis P, Fabeck L, Smets P, et al. (1998) Use of an intramedullary hip-screw compared with a compression hip-screw with a plate for intertrochanteric femoral fractures. A prospective, randomized study of one hundred patients. J Bone Joint Surg Am 80(5): 618-630.

11. Aune AK, Ekeland A, Odegaard B, Grogaard B, Alho A (1994) Gamma nail vs. compression screw for trochanteric femoral fractures 15 reoperations in a prospective, randomized study of 378 patients. Acta Orthop Scand 65(2): 127-130.

12. Goldhagen PR, O'Connor DR, Schwarze D, Schwartz E (1994) A prospective comparative study of the compression hip screw and the gamma nail. J Orthop Trauma 8(5): 367-372.

13. Utrilla AL, Reig JS, Munoz FM, Tufanisco CB (2005) Trochanteric gamma nail and compression hip screw for trochanteric fractures: a randomized, prospective, comparative study in 210 elderly patients with a new design of the gamma nail. J Orthop Trauma 19(4): 229-233.

\section{Your next submission with Juniper Publishers will reach you the below assets}

- Quality Editorial service

- Swift Peer Review

- Reprints availability

- E-prints Service

- Manuscript Podcast for convenient understanding

- Global attainment for your research

- Manuscript accessibility in different formats

( Pdf, E-pub, Full Text, Audio)

- Unceasing customer service

Track the below URL for one-step submission https://juniperpublishers.com/online-submission.php 